ECONOMICS

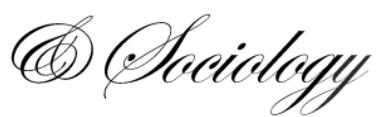

Kuzmenko, O., Vasylieva, T., Vojtovič, S., Chygryn, O., \& Snieška, V. (2020). Why do regions differ in vulnerability to COVID-19? Spatial nonlinear modeling of social and economic patterns. Economics and Sociology, 13(4), 318-340. doi:10.14254/2071-789X.2020/13-4/20

\title{
WHY DO REGIONS DIFFER IN VULNERABILITY TO COVID-19? SPATIAL NONLINEAR MODELING OF SOCIAL AND ECONOMIC PATTERNS
}

\author{
Olha Kuzmenko \\ Sumy State University, \\ Sumy, Ukraine \\ E-mail: \\ o.kuzmenk.0@uabs.sumdu.edu.ua \\ ORCID 0000-0001-8575-5725
}

Tetyana Vasylieva

Sumy State University,

Sumy, Ukraine

E-mail:

tavasilyeva@,fem.sumdu.edu.ua

ORCID 0000-0003-0635-7978

\section{Sergej Vojtovič}

Alexander Dubcek University of

Trencin, Trencin, Slovakia

E-mail:sergej.vojtovic@tnuni.sk

\section{Olena Chygryn \\ Sumy State University, \\ Sumy, Ukraine \\ E-mail: \\ o.chygryn@econ.sumdu.edu.ua \\ ORCID 0000-0002-4007-3728}

\author{
Vytautas Snieška \\ Kaunas University of Technology, \\ Lithuania \\ vytautas.snieska@,ktu.lt \\ ORCID 0000-0001-8777-273X
}

ABSTRACT. Certain groups of determinants (economic, environmental, social, healthcare) with the highest vulnerability identify the reasons for regional differentiation in morbidity and mortality from COVID19. This defines the necessity to find appropriate combinations of factors characterizing the vulnerability of a region. The methodology and tools to explain the regional specifics of population vulnerability to COVID19 are investigated through a systematic consideration of many public health factors, environmental, social and economic specific nature of regions. The aim of the article is to study the reasons for regional differentiation of population vulnerability (morbidity and mortality rates) from COVID-19. The authors investigate a nonlinear spatial model in which the stepwise algorithm of individual factor variables is added/removed from the model specifications step by step by the Aitken method depending on their correlation with morbidity and mortality from COVID-19 in the region. The FarrarGlober method is used to eliminate the multicollinearity of factors, the Spearman test is used to detect the heteroskedastic effect, and the Darbin-Watson test is used to check the presence of autocorrelation between the residues. As a result, the specification of the model with the highest adequacy in terms of $\mathrm{p}$-value and $\mathrm{t}$ statistics is formed. Relevant socioecological-economic vulnerability indices of regions to mortality and morbidity from COVID-19 are identified. The obtained results allow making adjustments in the state and regional programs concerning the mobilization of economic and healthcare systems.

Received: April, 2020

1st Revision: October, 2020

Accepted: December, 2020

DOI: $10.14254 / 2071-$

789X.2020/13-4/20 
JEL Classification: C21, C51,

C 31, C12, I15, I18, R58, R11

Keywords: COVID-19, vulnerability, modelling, public health.

\section{Introduction}

At the beginning of October 2020, the number of reported deaths in the world caused by COVID-19 exceeded 1 million. At the same time, a high reproductive index (as of October 2020, it was - 2.5-2.9) indicated the extraordinary rate of growth in infected people around the world, thus characterizing the rapid spread of the virus. For comparison, during the Spanish flu pandemic, when in 1918 about 50 million people on the planet died, that index was 1.7-2.09. The catastrophic rate of COVID-19 spread has led to a rapid and powerful response from international institutions and governments, which take different measures, primarily to reduce the pandemic rate and the catastrophically rising incidence. At the level of individual states and between the countries, appropriate measures include: closure of educational institutions, prohibition of mass gatherings, social distancing, restriction of movement, closure of borders, etc.

The global increase in morbidity and mortality caused significant changes in the regional socioeconomic development, emphasizing the relevance of studying the impact made by existing regional features on the vulnerability of population to COVID-19. It is evident that the morbidity and mortality level among the patients with COVID-19 depends on many factors, including employment and unemployment rates; migration movement; birth and death rates; income; the number of first registered cases by 19 classes of diseases; the number of laboratory tests performed on COVID-19, the number of contracts for medical care for population under various programs, the readiness of medical institutions to receive patients; environmental pollution; economic indices of regional development. Therefore, the definition of the most important economic, environmental, social, and public health factors, which have accumulated over the years and eventually formed the so-called "retrospective portrait of the vulnerability of population from different regions to COVID-19", is especially relevant today.

\section{Literature review}

The scientific community, namely, Cuddington et al., 1994; Haacker, 2002; Arndt et al., 2001; Bell et al., 2004, Bhargava et al., 2001, has made significant progress in identifying socioeconomic drivers or inhibitors of the spread of infectious diseases similar to COVID-19. Recent studies include an analysis of the national and regional specifics of the population's vulnerability to COVID-19: the study (Farseev et al., 2020) statistically finds links between the dynamics of the COVID- 19 spread and economic environment and public health factors; the work of Y. Ji et al. (2020) - links between mortality from COVID-19 and the availability of resources in the healthcare system. Recent studies have empirically confirmed that the level of interstate, interregional and intraregional migration is an important catalyst for the disease spread: the work of Z. Chen et al. (2020) proves the statistical relationship between the initial emigration from Wuhan and the infection spread dynamics to other cities in China; the work of Y. Bai et al. (2020) discovers that asymptomatic migrants could transmit COVID-19.

Besides, some traditional socio-economic factors are determinants of regions' vulnerability to COVID-19. The article studies the migration phenomenon and its linkages on fiscal revenues and budget expenditures with social benefits (Cristea et al., 2019; Levchenko et 
al., 2017; Didenko et al., 2020b). The research (Osabohien et al., 2020; Rajan, 2018; Shammi et al., 2020) showed that social protection positively affects employers' health and work outcomes through various channels, namely, building human resources and equity, the use of public resources, social inclusion. In their study, authors (Sasongko et al., 2019; Vasilyeva et al., 2019) implemented the Granger Causality test and Vector Autoregression to define the causality between inflation and unemployment. The article (Vydrová \& Bejtkovský, 2018; Papo et al., 2020) identified the key features of management bodies in public healthcare organizations that directly affect social maturity, intelligence, workers. The conclusions (Hedvicakova et al., 2018; Yelnikova et al., 2020) showed that the benefits, offered to employee, do not affect the labour market situation and public health. The authors (Lewandowska et al., 2020; Dutta et al., 2020; Jafarzadeh et al., 2019; Vasylieva et al., 2020) examined the institutional and educational determinants. Authors (Çera et al., 2019; Kashyap et al., 2020) used the principal component analysis and non-parametric methods to explore the linkages between entrepreneurial and social factors. The paper (Didenko et al., 2020a) investigated the relationship between behavioral aspects of populations' financial inclusion and social safety level. Authors (Mihi-Ramire et al., 2020; Bagmet et al., 2018) concluded that social strategies and policies use and promote the interaction between employer mobility factors since they allow companies and employees to diversify their risks and find new trade and investment opportunities. The paper (Melnyk et al., 2018) determined the relationships between institutional efficiency and identified areas of stability achieved by local governments in their roles. The studies (Grabara et al., 2019; Lyulyov, 2017) analyzed industry development stages with their management strategies, impact on employees, and their social and health state.

Significant scientific progress has been made in predicting the macroeconomic and social consequences of introducing certain restrictive measures during pandemics and identifying the channels through which quarantine mostly affected the economy and society. In the work of Liu et al. (2005), authors consider such channels as a reduction in the consumption of specific goods and services, an increase in the business's operating costs, and a reassessment of macroeconomic risks. The study of Lee et al. (2003) investigated the global trajectories of financial and economic shocks from epidemics outside the affected countries, the dependence of their spread dynamics on the morbidity level in countries where the virus originated, and the population's vulnerability degree to the migration flows. The work of Meltzer et al. (1999) described various models (including Oxford) to predict the probable economic consequences of past pandemics for the economy.

Scientists (Kusuma et al., 2020; Dave, 2019; Harafonova et al., 2017) emphasize that long-term investment is a new area for the researcher given the Covid-19.

Their results show the positive association between defensive pessimism, purchase intention and long-term investment, and mindset priming's positive mediation. The article (Sułkowski, 2020; Grshybowskyj, 2019) attempts to diagnose the impact of the Covid-19 pandemic on global trends, including organizational processes in enterprises and challenges for organization leaders in many areas. The papers (Bryl, 2020; Rudenko, 2020) indicates the influence of the long-term development of the chosen human capital indices and public health policies. The articles (Bobáková, 2017; Kot, 2020; Chygryn, 2018) assess fiscal decentralization in self-governing regions and improve the public health sphere. The papers (Bilan et al., 2019; Djalilov et al., 2015; Luchko, Arzamasova \& Vovk, 2019; Sumiyana, 2020; Vasylieva et al., 2019) investigate the relationship between macroeconomic stability, aggregate of accounting earnings, and national indicators economies. Authors (Lapinskienė et al., 2017; Tunčikienè et al., 2017) investigated economic growth, greenhouse gas emissions and other factors concerning health system occupational safety and health services. Implications created by (Senol et al., 2020) bring the conclusion that life insurance contributes more to economic 
growth with the long-term and regular resources it provides to save public health. Scientist (Svabova et al., 2020) analyzed the earnings level and fraudulent manipulation in financial reporting in decreasing the population's wealth.

The studies (Rui et al., 2019; Cebula et al., 2018; Bilan et al., 2018) analyzed the environmental factors and their effects on the economy's resilience to systemic crises. The work (Mentel et al., 2018) theoretically substantiates that the regional environmental state is a driving force for the stable growth of the overall national health. The authors in the study (Lyulyov et al., 2015; Hens et al., 2019) systematized the theoretical aspects, analyzing the environment in the regional and sectoral context.

The existing system of public health management, the level of funding, and the medical sector's development significantly impact regional vulnerability to COVID-19 (Khomenko et al., 2020; Smiianov et al., 2017). The paper (Sokol et al., 2020) generalized methods to assess risk factors of treatment failure outcomes; the authors (Sułkowski, 2020; Shammi et al., 2020) investigated the impact of COVID-19 on global development trends; the article (Smiianov, 2014) studied the internal audit system in healthcare system management.

At the same time, all these studies do not consider the healthcare system specifics in a particular country, differences in national statistical accounting systems, approaches to determining mortality, etc., so the intergovernmental analysis may not give accurate estimates and conclusions.

\section{Methodological approach}

The study hypothesizes the regional differentiation conditionality of morbidity and mortality from COVID-19 by specific patterns of factors in which the vulnerability is the highest.

The study of the regional vulnerability to COVID-19 includes the following stages:

1) formalization of the nonlinear multifactorial regression equations of dependence between the result (morbidity and mortality of the population from COVID-19) and variables public health factors (over 20 major classes of diseases) and determinants of environmental, social and economic specificity region (formula 1 ):

$$
y=a_{0}+a_{1} x_{1}+a_{2} x_{2}+\cdots+a_{23} x_{23}
$$

where $a_{0}$ - free member, $a_{i}$ - coefficients of the linear regression equation, $x_{i}$-factors, which are independent variables, $i=(1,23)$.

2) formation of correlation matrices that settle at which combinations of factors the studied influence will be the most statistically significant. A gradual algorithm will be used to add and remove variables from the equation due to their importance regarding the impact on the morbidity/mortality level from COVID-19;

3 ) the investigation of several models is planned step by step, by Aitken's method with a decrease in the number of variables. They will be compared with each other in terms of adequacy and the strength of factor variables' influence on the effective one. The parameters of the model adequacy will be p-values and t-statistics. The variables will not be included in the model if there is no improvement in the level of adequacy of the model;

4) the Farrar-Glober method will be used to eliminate the multicollinearity of factors, the Goldfeld-Kwantt parametric test - to detect the heteroskedasticity effect, the Aitken method - to eliminate this effect, and the Darbin-Watson test - to check the residual autocorrelation. 


\section{Conducting research and results}

24 regions of Ukraine and Kyiv are selected as the object to study the regional differentiation of morbidity and mortality from COVID- 19.

The information base of the study consists of indices of social (68 indicators), economic (42 indicators) development, state of the environment (12 indicators) and public health (39 indicators) for the period March - September 2020.

According to the stages defined in the research methodology, we present an assessment of regions' vulnerability to COVID-19.

We calculate the critical value of the $\chi$-square criterion, with a significance level of $95 \%$ and the number of freedom degrees $v(2)$ :

$$
\begin{aligned}
& v=\frac{1}{2}(m-1) m=253 \\
& \chi_{t a b}^{2}(0,05 ; 253)=291
\end{aligned}
$$

where $m$ - number of independant variables of the investigated model, $\chi_{t a b}^{2}$ - table value of the xi-square criterion.

The empirical value of $\chi$-square is as follows:

$$
\chi_{e m p}^{2}=-\left[n-1-\frac{1}{6}(2 m+5)\right] \ln (\Delta r)
$$

where $\chi_{e m p}^{2}$ - empirical value of chi-square criterion, defined by the investigated model, $n$ - row length for each factor, $\Delta r$ - determinant of the matrix.

The result is $\chi_{e m p}^{2} \approx 5489$, which significantly exceeds the critical value (3).

Thus, there is multicollinearity in the input array, and it is necessary to determine the correlation for each variable. So, we find the matrix $C$ inverse to the correlation matrix of even coefficients $r$. We find the empirical value of Fisher's criterion for each diagonal element $c_{j j}$ of this matrix. It will allow confirming or refuting the hypothesis regarding the studied index multicollinearity with others:

$$
F_{j e m p}=\left(c_{j j}-1\right) \frac{n-m}{m-1}
$$

where $F_{j e m p}$ - empirical value of Fisher's critrion, $c_{j j}$ - diagonal element of the matrix r, $n$ - row length for each factor, $m$ - number of independant variables of the observed model.

We divide data into two parts $m_{1}=m_{2}=19$ to perform calculations by this algorithm. The critical value of $F_{t a b}(0.05 ; 6 ; 18)=2.6$. Each calculated value of the Fisher's criterion exceeds the tabular one. Thus, it is necessary to determine the pairwise correlation coefficients using Student's t-test to exclude the factors with the highest absolute value (table 1).

Table 1. Features of multiple regression

\begin{tabular}{ccccc}
\hline $\begin{array}{c}\text { Multiple } \\
\text { correlation } \\
\text { coefficient }\end{array}$ & $\begin{array}{c}\text { Determination } \\
\text { coefficient }\end{array}$ & $\begin{array}{c}\text { Adjusted } \\
\text { determination } \\
\text { coefficient }\end{array}$ & $\begin{array}{c}\text { Fisher's } \\
\text { criterion } \\
\mathrm{F}(1,23)\end{array}$ & $\begin{array}{c}\text { Standardized } \\
\text { error }\end{array}$ \\
\hline 0,728 & 0,530 & 0,510 & 25,967 & 4548,657 \\
\hline
\end{tabular}

Source: own calculation

Ridge regression will effectively reduce the dimension of the regression model. We determine the most significant coefficients and exclude the least influential predictors (have the 
lowest value of $\mathrm{R}$ or the largest value of $\mathrm{P}$ or $\mathrm{F}$ criterion (table 2 ) on the resulting variable. The gradual exclusion will continue until we obtain a data set at which the equation regressions will contain only significant coefficients (table 3 ).

Table 2. Ridge regression of inclusion/exclusion

\begin{tabular}{|c|c|c|c|c|c|c|c|}
\hline & $\begin{array}{l}\text { Step - } \\
+ \text { in/- } \\
\text { out* }\end{array}$ & $\begin{array}{l}\text { Multiple - } \\
\mathrm{R}^{*}\end{array}$ & $\begin{array}{l}\text { Multiple - } \\
\text { R-square* }\end{array}$ & $\begin{array}{l}\text { R-square - } \\
\text { change* }\end{array}$ & $\begin{array}{c}\text { F - to - } \\
\text { entr/rem* }\end{array}$ & p-level* & $\begin{array}{c}\text { Variables } \\
- \\
\text { included* }\end{array}$ \\
\hline $\begin{array}{l}\text { Volumes of capital investments in environmental } \\
\text { protection, 2019, thousand UAH }\end{array}$ & -1 & 0,9370 & 0,8780 & $-0,0001$ & 0,0008 & 0,9820 & 22 \\
\hline $\begin{array}{l}\text { Volumes of light oil product stocks and gas at gas } \\
\text { stations (motor gasoline) - total, tons }\end{array}$ & -2 & 0,9369 & 0,8778 & $-0,0001$ & 0,0021 & 0,9674 & 21 \\
\hline $\begin{array}{l}\text { Enterprises' costs for staff by their size by region in } \\
2019 \text {, million, UAH }\end{array}$ & -3 & 0,9368 & 0,8777 & $-0,0002$ & 0,0042 & 0,9524 & 20 \\
\hline Number of junior staff, persons & -4 & 0,9367 & 0,8775 & $-0,0002$ & 0,0064 & 0,9399 & 19 \\
\hline $\begin{array}{l}\text { Transferred on a part-time basis (week) for } \\
\text { economic reasons, thousand people }\end{array}$ & -5 & 0,9366 & 0,8772 & $-0,0003$ & 0,0110 & 0,9205 & 18 \\
\hline $\begin{array}{l}\text { Labor costs of enterprises by their size Total, } \\
\text { million UAH }\end{array}$ & -6 & 0,9364 & 0,8769 & $-0,0003$ & 0,0144 & 0,9083 & 17 \\
\hline $\begin{array}{l}\text { Symptoms, features and divergencies detected } \\
\text { during laboratory and clinical studies (not classified } \\
\text { in other sections) }\end{array}$ & -7 & 0,9362 & 0,8764 & $-0,0005$ & 0,0294 & 0,8687 & 16 \\
\hline Migration growth, ages $0-4$ & -8 & 0,9355 & 0,8752 & $-0,0012$ & 0,0753 & 0,7907 & 15 \\
\hline $\begin{array}{l}\text { Average monthly salary by sex (men) and regions } \\
\text { per the quarter, UAH }\end{array}$ & -9 & 0,9346 & 0,8735 & $-0,0018$ & 0,1280 & 0,7287 & 14 \\
\hline $\begin{array}{l}\text { The number of registered diseases of the endocrine } \\
\text { system, eating disorders, metabolic disorders }\end{array}$ & -10 & 0,9334 & 0,8713 & $-0,0022$ & 0,1708 & 0,6882 & 13 \\
\hline $\begin{array}{l}\text { Volumes of stocks of light oil products and gas at } \\
\text { gas stations, propane and butane liquefied, tons }\end{array}$ & -11 & 0,9320 & 0,8687 & $-0,0026$ & 0,2210 & 0,6475 & 12 \\
\hline $\begin{array}{l}\text { Volume of accumulated waste in specially } \\
\text { designated places and facilities, thousand tons }\end{array}$ & -12 & 0,9306 & 0,8659 & $-0,0028$ & 0,2529 & 0,6241 & 11 \\
\hline $\begin{array}{l}\text { Volumes of carbon dioxide emissions into the } \\
\text { atmosphere by region, thousand tons }\end{array}$ & -13 & 0,9278 & 0,8608 & $-0,0051$ & 0,4940 & 0,4946 & 10 \\
\hline $\begin{array}{l}\text { The average number of agricultural part-time, } \\
\text { workers, thousand people }\end{array}$ & -14 & 0,9246 & 0,8549 & $-0,0060$ & 0,6022 & 0,4507 & 9 \\
\hline $\begin{array}{l}\text { Number of employees with a scientific degree } \\
\text { involved in the research and development, persons }\end{array}$ & -15 & 0,9209 & 0,8480 & $-0,0069$ & 0,7108 & 0,4124 & 8 \\
\hline Retail turnover under bank loan agreements & -16 & 0,9173 & 0,8415 & $-0,0065$ & 0,6875 & 0,4192 & 7 \\
\hline $\begin{array}{l}\text { Number of specialized doctors (infectologists, } \\
\text { therapists, pediatricians) }\end{array}$ & -17 & 0,9092 & 0,8266 & $-0,0148$ & 1,5891 & 0,2245 & 6 \\
\hline $\begin{array}{l}\text { Number of agreements on medical care for the } \\
\text { population under the program of medical guarantees }\end{array}$ & -18 & 0,9010 & 0,8118 & $-0,0149$ & 1,5431 & 0,2301 & 5 \\
\hline $\begin{array}{l}\text { Number of interstate migrants (migration increase), } \\
\text { reduction }(-) \text {, persons }\end{array}$ & -19 & 0,8834 & 0,7804 & $-0,0314$ & 3,1703 & 0,0910 & 4 \\
\hline Migration growth, aged $70-74$ & -20 & 0,8495 & 0,7216 & $-0,0588$ & 5,3525 & 0,0315 & 3 \\
\hline $\begin{array}{l}\text { Costs for environmental protection by regions in } \\
2019 \text { (thousand UAH) }\end{array}$ & -21 & 0,7976 & 0,6361 & $-0,0855$ & 6,4472 & 0,0191 & 2 \\
\hline $\begin{array}{l}\text { The number of laboratory tests performed by PCR } \\
\text { on COVID-19 pf 01/10/2020 }\end{array}$ & -22 & 0,7282 & 0,5303 & $-0,1058$ & 6,3968 & 0,0191 & 1 \\
\hline
\end{tabular}

* Symbols: Step - +in/-out - on/off step number; Multiple - R - multiple correlation coefficient; Multiple - R-square - coefficient of determination; R-square - change - determination coefficient, adjusted for the number of freedom degrees; F - to - entr/rem F on / off criterion; p-level - level of significance; Variables - included - the sequence number of the variable

Source: own calculation

The quality characteristics of the model (table 3 ) indicate a high quality of adjusted model to the studied variables, all values of t-statistics are greater than critical one. Indices of migration and carbon emissions are directly related to the number of infected patients. Indices which show the readiness of medical institutions and the population to respond to pandemic challenges are inversely related. 
Table 3. The results of ridge regression

\begin{tabular}{|c|c|c|c|c|c|c|}
\hline & Beta* & $\begin{array}{c}\text { Std.Err. } \\
\text { - of } \\
\text { Beta* }^{*}\end{array}$ & $\mathrm{~B}^{*}$ & $\begin{array}{l}\text { Std.Err. - } \\
\text { of } \mathrm{B}^{*}\end{array}$ & $*$ & p-level \\
\hline Free member of the regression & & & $-2708,59$ & 2113,430 & $-1,282$ & 0,217 \\
\hline Number of beds in infectious diseases departments & 0,423 & 0,206 & 5,350 & 2,609 & 2,050 & 0,056 \\
\hline $\begin{array}{c}\text { Volume of accumulated waste in specially designated } \\
\text { places and facilities, thousand tons }\end{array}$ & $-0,220$ & 0,127 & 0,000 & 0,000 & $-1,735$ & 0,101 \\
\hline $\begin{array}{l}\text { The number of laboratory tests performed by PCR on } \\
\text { COVID-19 pf 01/10/2020 }\end{array}$ & 0,289 & 0,108 & 1,390 & 0,523 & 2,668 & 0,016 \\
\hline $\begin{array}{c}\text { Number of interstate migrants (migration increase), } \\
\text { reduction }(-) \text {, persons }\end{array}$ & $-0,190$ & 0,094 & $-3,330$ & 1,654 & $-2,015$ & 0,060 \\
\hline $\begin{array}{c}\text { Volumes of carbon dioxide emissions into the atmosphere } \\
\text { by region, thousand tons }\end{array}$ & $-0,234$ & 0,120 & $-0,230$ & 0,118 & $-1,943$ & 0,069 \\
\hline $\begin{array}{c}\text { Number of agreements on medical care for the population } \\
\text { under the program of medical guarantees }\end{array}$ & 0,243 & 0,147 & 16,590 & 10,031 & 1,654 & 0,117 \\
\hline $\begin{array}{c}\text { Number of specialized doctors (infectologists, therapists, } \\
\text { pediatricians) }\end{array}$ & 0,165 & 0,163 & 11,760 & 11,626 & 1,011 & 0,326 \\
\hline
\end{tabular}

* Symbols: Beta Std.Err. - of Beta - standardized regression coefficient and its standardized error; B / Std.Err. - of B - non-standardized regression coefficient and its standardized error; $\mathrm{t}(17)$ - $\mathrm{t}$ - statistics with the number of freedom degrees 17; p-level - the level of coefficient significance; Multiple - R - multiple correlation coefficient; Multiple - R-square - determination coefficient; Adjusted R-square is a determination coefficient adjusted for the number of freedom degrees.

Source: own calculation

The gradual exclusion for the regressor "Number of confirmed cases of coronavirus (y)" gave the following result:

$$
y=-3,33 a_{1}-0,23 a_{2}+1,39 a_{4}+16,59 a_{5}+5,35 a_{6}+11,76 a_{7}-2708,59,
$$

where $\mathrm{a}_{1}$ - number of interstate migrants (migration growth, reduction), persons; $\mathrm{a}_{2}$ volumes of carbon dioxide emissions into the atmosphere in regions, thousand tons; $\mathrm{a}_{3}$ - the amount of waste accumulated during operation, in specially designated places and facilities, thousand tons; $\mathrm{a}_{4}$ - the number of laboratory tests performed on COVID-19; $\mathrm{a}_{5}$ - the number of agreements on medical care for the population under the program of medical guarantees; $\mathrm{a}_{6}$ the number of beds in infectious diseases departments; $a_{7}$ - the number of specialized doctors (infectologists, therapists and pediatricians).

At this stage, the index $a_{4}$ - the number of laboratory tests on COVID-19, is a control point for the studied variable, characterizing the number of infected with coronavirus, i.e., the variable for checking the quality to reduce risk. These two indices are interrelated, and the model is adequate given the fact that as a result of our study (5) we obtained a direct relationship, i.e. with increasing number of tests, the number of new infections increases proportionally. To check the presence or absence of a relationship between two sets: the value of the dependent variable - the number of confirmed cases of coronavirus and the set of values that were included in the model (5), we use canonical analysis and univariate tests of significance, effect sizes, and powers for sigma-restricted parameterization. For canonical analysis we use the program Statistica Portable, the tools of Statistics/Multivariate Exploratory Techniques/Canonical Analysis. For sigma-restricted parameterization we use the program Statistica Portable, the tools of Advanced Linear/Nonlinear Models/General Regression Models.

The results of canonical analysis (table 4) confirmed the presence of relationship between the explained variable and the independent ones because the indicator total redundancy is $86 \%$ at the p-value less than 0,0001 that means: the variation of the number of confirmed 
cases of coronavirus by $86 \%$ is explained by exactly 7 considered regressors. Also, the value of the actual chi-square $(39,15)$ significantly exceeds the critical value $(13,85)$, which confirms the presence of a close relationship of factors $\mathrm{a}_{i}, i=1 . .7$, which were included in the model (5) and the explained variable. The analyses of sigma-restricted parameterization is also provided confirmation of the significance of the input data: the $\mathrm{R}$ square value for the indicators (the number of agreements on medical care for the population under the program of medical guarantees; the number of beds in infectious diseases departments; the number of specialized doctors) is over 0,817 , indicating that these data describe the model well. For indicators the number of laboratory tests performed on COVID-19, the amount of waste accumulated during operation, in specially designated places and facilities, volumes of carbon dioxide emissions into the atmosphere in regions $\mathrm{R}$ square is in the range of $0,518-0,615$, but with $\mathrm{p}$-values less than 0,05 , which confirms the significance of these factors for the dependent variable the number of confirmed cases of coronavirus.

Table 4. Results of canonical analysis: Chi-Square Tests with Successive Roots Removed

\begin{tabular}{ccccccc}
\hline Root Removed & Canonicl R & $\begin{array}{c}\text { Canonicl R- } \\
\text { sqr. }\end{array}$ & Chi-sqr. & df & p & $\begin{array}{c}\text { Lambda } \\
\text { Prime }\end{array}$ \\
\hline $\begin{array}{c}\text { Number of confirmed } \\
\text { cases of coronavirus }\end{array}$ & 0,9304 & 0,8657 & 39,1529 & 7,0000 & 0,0000 & 0,1343 \\
\hline $\begin{array}{c}\text { number of confirmed } \\
\text { deaths from COVID-19 }\end{array}$ & 0,8877 & 0,7879 & 30,2425 & 7,0000 & 0,0001 & 0,2121 \\
\hline
\end{tabular}

* Canonicl R-sqr. - total redundancy, Chi-sqr.- Chi square tests, p- the level of the coefficient significance

Source: own calculation

It is necessary to add nonlinear terms to the model, namely, consider a polynomial model of the second degree, clarify and strengthen the relationship between independent variables and factors. So, for variables $a_{i}, i=1 . .7$, obtained at the previous stage, we add terms that will contain $a_{i}{ }^{2}, i=1 . .7$, and the final model will look like as follows (6):

$$
y=k_{11} a_{1}^{2}+k_{12} a_{1}+k_{21} a_{2}^{2}+k_{22} a_{2}+\cdots+k_{71} a_{7}^{2}+k_{72} a_{7}+k_{0} .
$$

where $a_{i}$ - regressors, $k_{i 1}$ - coefficient with $a_{i}^{2}, k_{i 2}$ - coefficient with the linear constituent $a_{i}, i=(1,7)$ - number of the variable, $k_{0}$-free member.

According to Wald's criterion, the linear coefficients are the most significant in this model with such variables as carbon dioxide emissions into the atmosphere, the number of medical care contracts under the medical guarantees program, and the number of laboratory tests by PCR on COVID-19.

Table 5. Description of quadratic multiple regression coefficients

\begin{tabular}{ccc}
\hline & $\begin{array}{c}\text { Wald - } \\
\text { Stat. }\end{array}$ & $\mathrm{p}^{*}$ \\
\hline Free member of the regression & 139,2081 & 0,000000 \\
\hline Number of interstate migrants (migration growth), reduction (-), persons & 0,1210 & 0,727923 \\
\hline Number of interstate migrants (migration growth), reduction (-), persons ^ 2 & - & - \\
\hline $\begin{array}{c}\text { Volumes of carbon dioxide emissions into the atmosphere by regions, thousand } \\
\text { tons }\end{array}$ & 19,9097 & 0,000008 \\
\hline $\begin{array}{c}\text { Volumes of carbon dioxide emissions into the atmosphere by regions, thousand } \\
\text { tons } \wedge \text { 2 }\end{array}$ & - & - \\
\hline $\begin{array}{c}\text { The amount of waste accumulated during operation in specially designated } \\
\text { places and facilities, thousands tons }\end{array}$ & - \\
\hline $\begin{array}{c}\text { Volume of accumulated waste in specially designated places and facilities, } \\
\text { thousand tons } \wedge \text { 2 }\end{array}$ & - \\
\hline
\end{tabular}




\begin{tabular}{|c|c|c|}
\hline $\begin{array}{l}\text { The number of laboratory tests performed by PCR on COVID-19 pf } \\
\qquad 01 / 10 / 2020\end{array}$ & 21,0981 & 0,000004 \\
\hline $\begin{array}{l}\text { The number of laboratory tests performed by PCR on COVID-19 pf } \\
\qquad 01 / 10 / 2020^{\wedge} 2\end{array}$ & - & - \\
\hline $\begin{array}{l}\text { Number of medical care agreements for the population under the program of } \\
\text { medical guarantees }\end{array}$ & 6,4909 & 0,010843 \\
\hline $\begin{array}{l}\begin{array}{l}\text { Number of medical care agreements for the population under the program of } \\
\text { medical guarantees } \wedge 2\end{array}\end{array}$ & 3,2389 & 0,071908 \\
\hline Number of beds in infectious diseases departments & 2,0133 & 0,155926 \\
\hline Number of beds in infectious diseases departments ${ }^{\wedge} 2$ & - & - \\
\hline Number of specialized doctors (infectologists, therapists, pediatricians) & 0,3515 & 0,553280 \\
\hline Number of specialized doctors (infectologists, therapists, pediatricians) $^{\wedge} 2$ & 2,1184 & 0,145537 \\
\hline
\end{tabular}

*Symbols: Wald - Stat. - the value of the Wald's criterion; P - the level of the coefficient significance.

Source: own calculation

As a result of calculations by (7), we obtain the polynomial regression coefficients of the second degree with seven unknowns. The result of the calculations is as follows:

$$
\begin{gathered}
y=7,5 \cdot 10^{-4} a_{1}^{2}-2,7 a_{1}+2,3 a_{2}^{2}-0,8 a_{2}-1,3 \cdot 10^{-10} \cdot a_{3}^{2}+4,4 \cdot 10^{-5} a_{3}-6,6 \\
10^{-4} a_{4}^{2}+6,7 a_{4}+2,2 \cdot 10^{-2} a_{5}^{2}-9,6 a_{5}-5,9 \cdot 10^{-6} a_{6}^{2}+11,2 a_{6}+1,4 a_{7}^{2}-18,5 a_{7}- \\
670,2
\end{gathered}
$$

Determination coefficient $R^{2}=0,96$, indicating the strong relationship between the dependent and independent variables. Fisher's test also gives a positive result: $F_{\text {em }}=9,3>2,6=$ $F_{t a b}(0,05 ; 7 ; 17)$. Thus, the regression equation is statistically significant, the model is suitable. Table 6 shows the values of the Cook's distance $D_{i}(1.15)$, used to determine the influence of data on the results of observations.

$$
D_{i}=\frac{\sum_{1}^{25}\left(\widehat{Y}_{l}-\widehat{Y}_{i / j}\right)^{2}}{7 M S E}
$$

where $D_{i}$ - the Cook's distance; $\widehat{Y}_{l}$ - theoretical value of $i$-observation; $\widehat{Y}_{i / j}$ theoretical value of $j$-observation without $i$-observation; MSE - standard error.

We check the presence or absence of autocorrelation, i.e., the relationship between random deviations and residual values in other observations. We implement Darbin-Watson test to check (9):

$$
D W=\frac{\sum \quad\left(e_{i}-e_{i-1}\right)^{2}}{\sum e_{i}^{2}}
$$

where $D W$ - Darbin-Watson test, $e_{i}$ - difference between theoretical and empirical level of $i$ - observation.

Table 6 demonstrates standardized residues and indicates the final observation error.

Table 6. Additional statistical indices of adequacy and significance of the model

\begin{tabular}{ccccc}
\hline & $\begin{array}{c}\text { General. - } \\
\text { Cook's D* }\end{array}$ & Diff- - Chi $^{*}$ & $\begin{array}{c}\text { Diff- } \\
\text { Likelihd* }\end{array}$ & $\begin{array}{c}\text { Std. D. - } \\
\text { Residual* }\end{array}$ \\
\hline Vinnytsia region & 0,948 & 1,40908 & 1437863 & 1,18705 \\
\hline Volyn region & 2,610 & 2,86844 & 2563999 & $-1,69365$ \\
\hline Dnepropetrovsk region & - & - & - & - \\
\hline Donetsk region & 73,330 & 7,82532 & 1288072 & 2,79738 \\
\hline
\end{tabular}




\begin{tabular}{ccccc}
\hline Zhytomyr region & 0,786 & 2,70734 & 3581361 & 1,64540 \\
\hline Zakarpattia region & 4,333 & 3,26122 & 2390733 & 1,80589 \\
\hline Zaporizhya region & 8,394 & 7,01873 & 5456251 & $-2,64929$ \\
\hline Ivano-Frankivsk region & 83,267 & 1,50413 & 45561 & 1,22643 \\
\hline Kyiv region & 0,385 & 0,04909 & 9478 & 0,22156 \\
\hline Kirovograd region & 0,003 & 0,52734 & 894650 & 0,72618 \\
\hline Luhansk region & 0,331 & 1,31862 & 1799110 & $-1,14831$ \\
\hline Lviv region & 1050,301 & 1,10672 & 1990 & $-1,05201$ \\
\hline Mykolayiv region & 11,625 & 2,96713 & 1029938 & $-1,72254$ \\
\hline Odessa region & 152,136 & 13,25711 & 1813998 & $-3,64103$ \\
\hline Poltava region & 0,000 & 3,82181 & 6524072 & 1,95494 \\
\hline Rivne region & 237,717 & 3,74881 & 99358 & 1,93619 \\
\hline Sumy region & 0,154 & 0,35727 & 426504 & 0,59772 \\
\hline Ternopil region & 12,151 & 0,33090 & 14975 & $-0,57524$ \\
\hline Kharkiv region & 903,272 & 13,80214 & 354615 & 3,71512 \\
\hline Kherson region & 2,435 & 7,13332 & 9078562 & $-2,67083$ \\
\hline Khmelnytsky region & 0,021 & 0,07588 & 101782 & 0,27546 \\
\hline Cherkasy region & 0,936 & 1,95562 & 2257919 & 1,39843 \\
\hline Chernivtsi region & 39,275 & 5,76919 & 1261386 & 2,40191 \\
\hline Chernihiv region & 0,038 & 0,17442 & 244724 & 0,41764 \\
\hline Kyiv & - & - & - & - \\
\hline
\end{tabular}

* Symbols: General. - Cook's D - Cook's distance; Diff- - Chi ${ }^{2}$ - the value of the Xi-square criterion; Diff- - Likelihd - likelihood ratio test; Std. D. - Residual - standardized residues.

Source: own calculation

Table 7 demonstrates the theoretical and empirical values of the COVID-19 diseases by regions and the residuals of the studied index. According to them, we see results quite close to the empirical ones in Donetsk, Dnipropetrovsk regions and Kyiv; and vice versa quite a high difference in such regions as Ivano-Frankivsk, Zaporizhia, Lviv, Mykolaiv, Chernivtsi and Kherson

Table 7. Theoretical and empirical values for regions of Ukraine

\begin{tabular}{lcccccc}
\hline & $\begin{array}{c}\text { Response }- \\
\text { Value* }\end{array}$ & $\begin{array}{c}\text { Pred. }- \\
\text { Value* }\end{array}$ & Residual* & $\begin{array}{c}\text { St. }- \\
\text { Error* }\end{array}$ & $\begin{array}{c}\text { Lower CL - } \\
95, \% *\end{array}$ & $\begin{array}{c}\text { Upper CL - } \\
95, \% *\end{array}$ \\
\hline Vinnytsia region & 6574,00 & 7152,808 & $-578,808$ & 0,154 & 3973,20 & 7271,07 \\
\hline Volyn region & 8571,00 & 10183,972 & $-1612,973$ & 0,089 & 8549,82 & 12102,55 \\
\hline $\begin{array}{l}\text { Dnepropetrovsk } \\
\text { region }\end{array}$ & 6917,00 & 6927,485 & $-10,485$ & 0,189 & 4779,14 & 10018,43 \\
\hline Donetsk region & 3743,00 & 3676,039 & 66,961 & 0,476 & 1025,60 & 6632,26 \\
\hline Zhytomyr region & 6285,00 & 5972,165 & 312,835 & 0,141 & 3331,17 & 5792,12 \\
\hline Zakarpattia region & 10089,00 & 10570,456 & $-481,456$ & 0,116 & 6811,84 & 10713,61 \\
\hline Zaporizhya region & 4502,00 & 7766,111 & $-3264,111$ & 0,141 & 5186,72 & 9014,63 \\
\hline $\begin{array}{l}\text { Ivano-Frankivsk } \\
\text { region }\end{array}$ & 14147,00 & 11070,726 & 3076,273 & 0,093 & 11613,31 & 16717,37 \\
\hline Kyiv region & 9717,00 & 10005,588 & $-288,588$ & 0,128 & 7486,55 & 12360,50 \\
\hline Kirovograd region & 1143,00 & 11,908 & 1131,092 & 0,521 & 71,06 & 546,90 \\
\hline Luhansk region & 1140,00 & 1650,289 & $-510,290$ & 0,235 & 1562,66 & 3940,00 \\
\hline Lviv region & 21045,00 & 23229,409 & $-2184,409$ & 0,061 & 18679,36 & 23810,82 \\
\hline Mykolayiv region & 3553,00 & 5675,974 & $-2122,974$ & 0,255 & 2769,50 & 7533,97 \\
\hline Odessa region & 14434,00 & 15364,256 & $-930,256$ & 0,079 & 13506,40 & 18438,29 \\
\hline Poltava region & 2556,00 & 2385,164 & 170,836 & 1,811 & 0,05 & 61,83 \\
\hline Rivne region & 12873,00 & 12278,627 & 594,373 & 0,103 & 10257,51 & 15373,93 \\
\hline Sumy region & 4973,00 & 4419,829 & 553,171 & 0,166 & 3121,10 & 5979,22 \\
\hline Ternopil region & 13977,00 & 13152,305 & 824,695 & 0,0914 & 11786,20 & 16866,53 \\
\hline Kharkiv region & 19948,00 & 18027,606 & 1920,394 & 0,067 & 16970,87 & 22068,39 \\
\hline
\end{tabular}




\begin{tabular}{lcccccc}
\hline Kherson region & 1259,00 & 4226,013 & $-2967,013$ & 0,154 & 3157,32 & 5780,38 \\
\hline $\begin{array}{l}\text { Khmelnytsky } \\
\text { region }\end{array}$ & 6700,00 & 6353,709 & 346,290 & 0,094 & 5299,36 & 7683,34 \\
\hline Cherkasy region & 4476,00 & 2896,943 & 1579,057 & 0,249 & 1821,63 & 4853,29 \\
\hline Chernivtsi region & 14754,00 & 10212,047 & 4541,953 & 0,089 & 11437,70 & 16244,63 \\
\hline Chernihiv region & 4409,00 & 4587,556 & $-178,557$ & 0,140 & 2969,99 & 5158,87 \\
\hline Kyiv & 24317,00 & 24305,009 & 11,990 & 0,053 & 21888,35 & 27019,40 \\
\hline
\end{tabular}

*Symbols: Response - Value - empirical values; Pred. - Value - theoretical values;

Residual - residuals; St. - Error - standard error; Lower CL,Upper CL - predicted values with a $95 \%$ confidence interval.

Source: own calculation

We compare the frequency histograms for theoretical and empirical values of the number of people infected with COVID-19 (Fig. 1, 2). According to calculations, there is an equal relative frequency at levels from 0 to 10,000 and from 20,000 to 25,000 patients. There is a distortion per unit between the data of 10-15 thousand and 15-20 thousand diseases, but this deviation is insignificant.

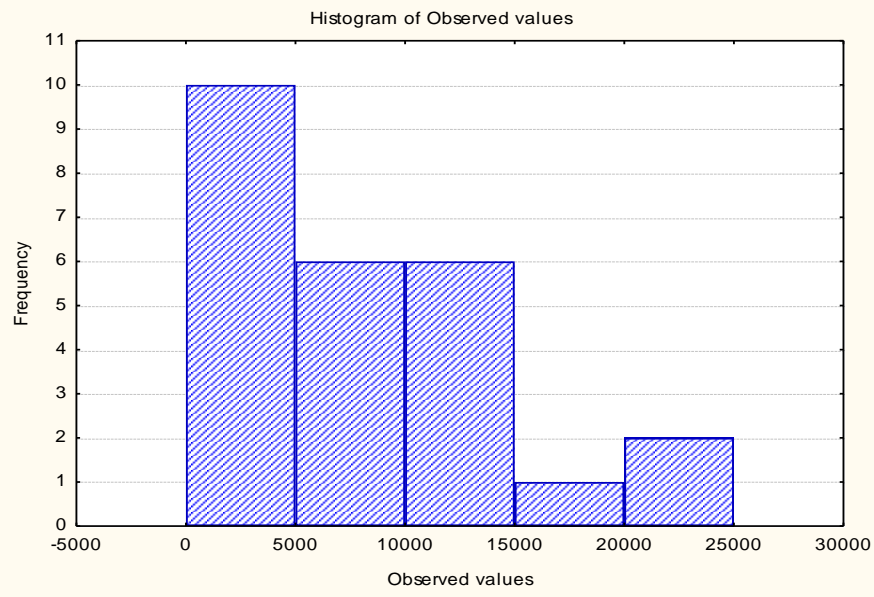

Figure 1. The relative frequency of empirical values for the number of infected with COVID19

Source: own compilation

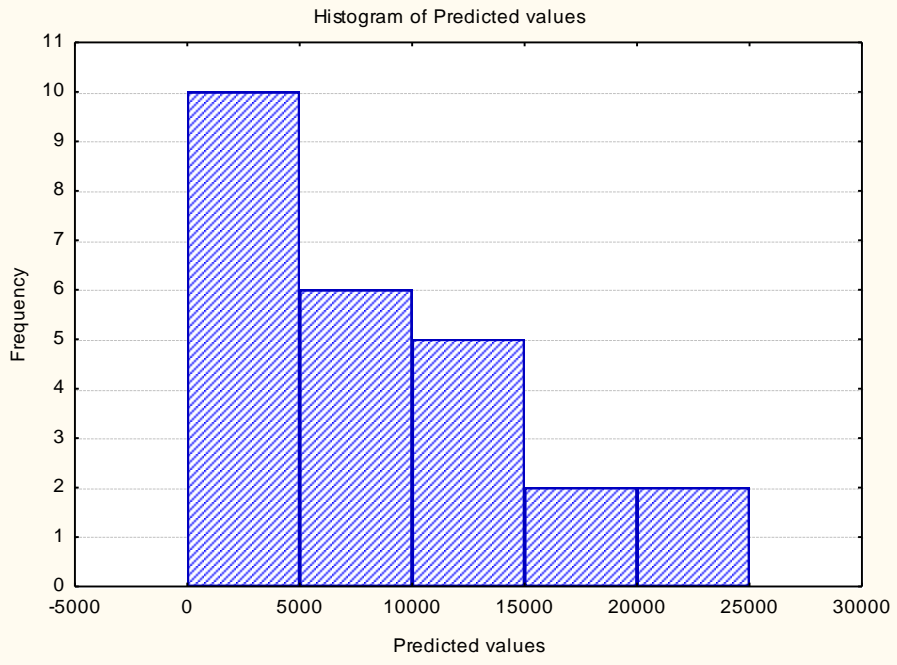

Figure 2. The relative frequency of theoretical values for the number of infected COVID-19 Source: own compilation 
We check the presence or absence of autocorrelation, i.e. the relationship between random deviations and residual values in other observations. We apply Darbin-Watson test to check (10):

$$
D W=\frac{\sum \quad\left(e_{i}-e_{i-1}\right)^{2}}{\sum e_{i}^{2}}
$$

where $D W$ - Durbin-Watson test, $e_{i}$ - the difference between theoretical and empirical level of $i$-observation. Having performed calculations, we receive $\mathrm{DW}=1,89$. Critical values of this criterion for the significance level are $\alpha=0,05, \mathrm{n}=25, \mathrm{~m}=7: d_{1}=0,94, d_{2}=1,9$.

The obtained result is outside the critical values. It means that there is a little autocorrelation of the residuals. Given this, the model is spatial, and we can ignore this fact.

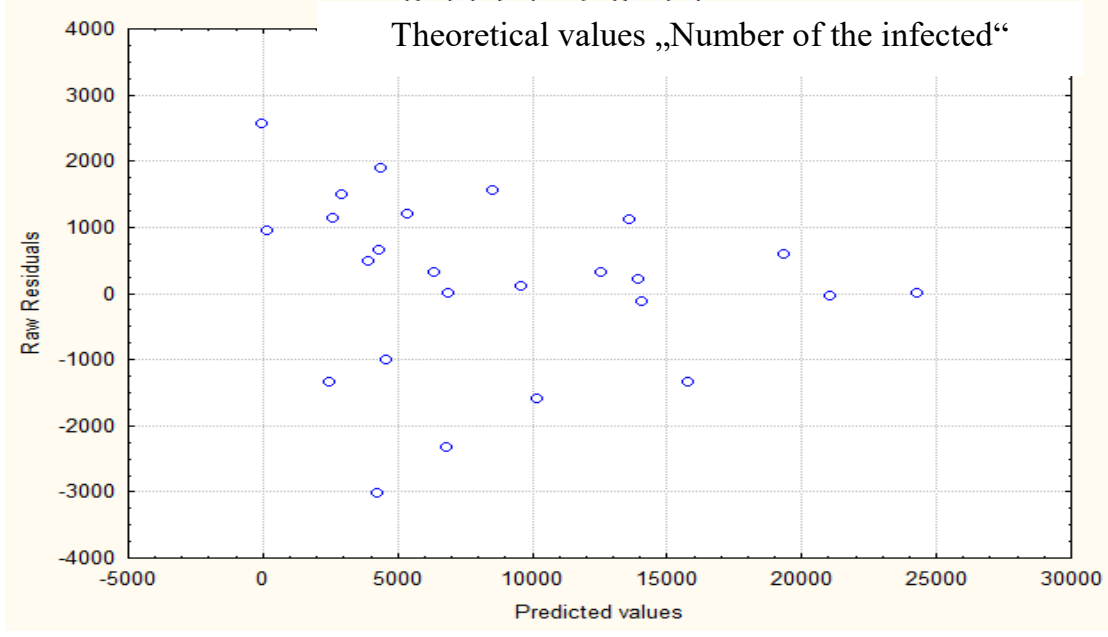

Figure 3. Residual graph (difference between empirical and theoretical values in the constructed model of the morbidity and mortality dependence on COVID-19 and on socio-ecological and economic factors

Source: own compilation

We analyze the graphs of the dependence of residuals $e$ on the variables included in the final model (Fig. 3.) to define the presence or absence of heteroskedasticity. 


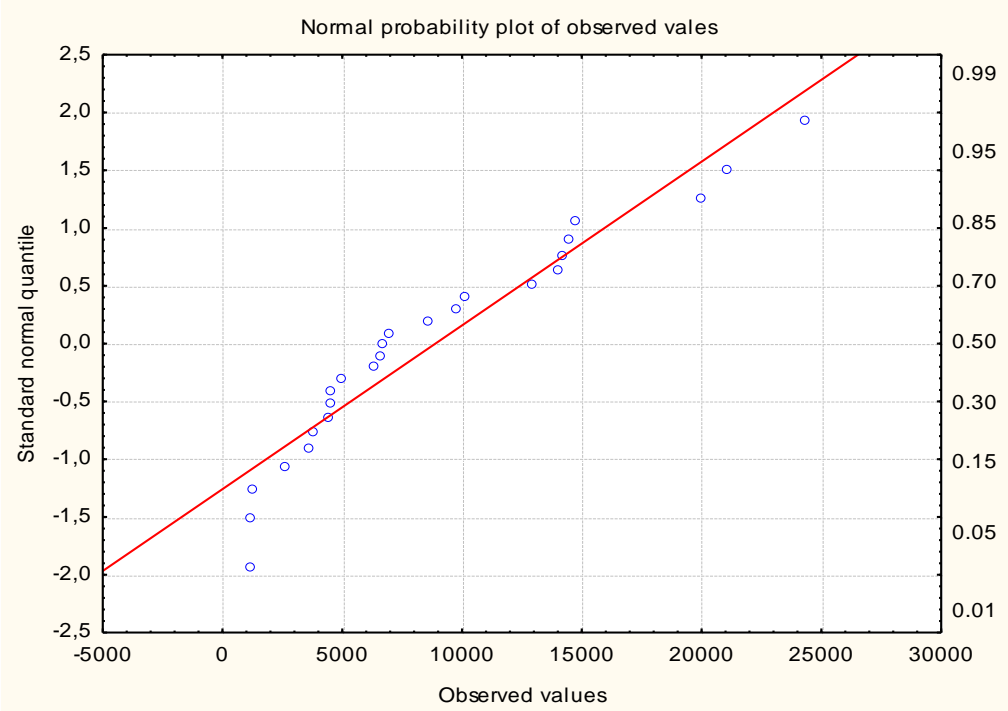

Figure 4. Normal probability plot

Source: own compilation

Figure 4 shows a normal probability plot, enabling to understand whether the studied values are normally distributed or not. First, all values are sorted from the smallest to the largest value, then the value of the z-test is calculated for each rank.

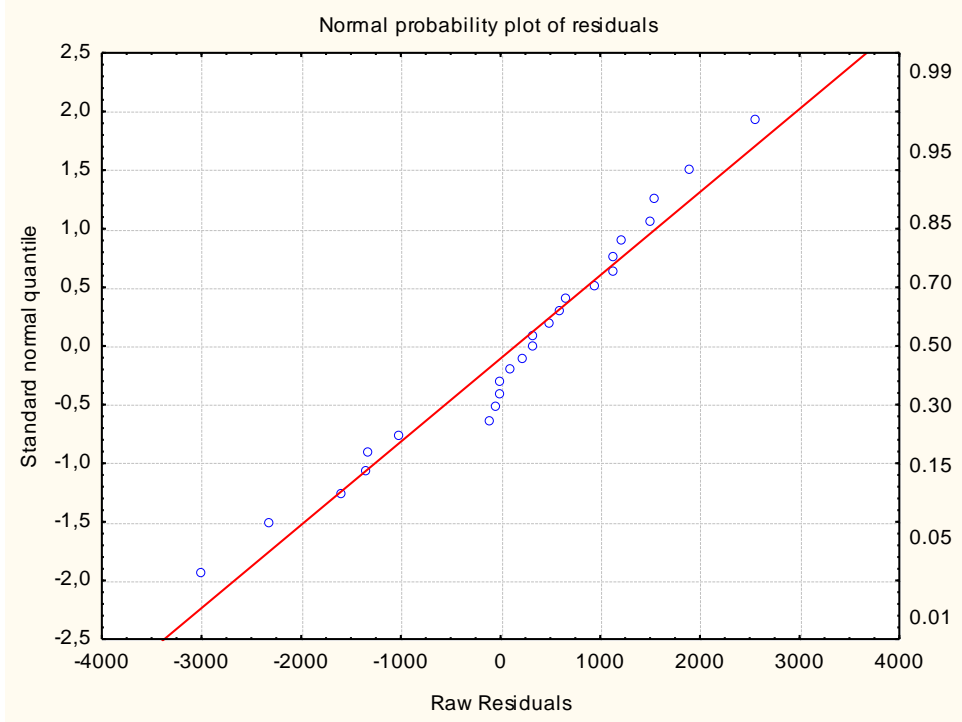

Figure 5. Normal residuals plot

Source: own compilation

In the case of a normal distribution, the obtained points should fall on a straight line. If there is a deviation from the straight line, the value is not normally distributed. In our case, there is a significant deviation from the line, indicating the lack of normal distribution in the studied data, which can distort the results.

Figure 5 shows a typical residual plot of the constructed model, which indicates that the residuals are distributed normally compared to the standard input data, although there are some emissions. Therefore, the model results are distributed closer to the normal distribution, and given the close relationship between empirical and theoretical values, the results can be used for further research. 
Using a similar method of detecting multicollinearity among the studied factors by formulas (1) - (10) and applying the method of gradual inclusion of variables, we obtain the following final arguments for the regressor "Number of confirmed deaths from COVID-19 (z)":

$$
z=-6,51 b_{1}-3,11 b_{2}-0,005 b_{3}+0,029 b_{5}+1,18 b_{6}+0,008 b_{7}-1255,9,
$$

where $b_{1}$ - registered unemployment on average for the period, thousand people; $b_{2}$ volumes of working time use and part-time employment per one full-time employee, $h ; b_{3}$ volumes of carbon dioxide emissions into the atmosphere, thousand tons; $\mathrm{b}_{4}$ - volumes of waste accumulated during operation, in specially designated places and facilities, thousand tons; $\mathrm{b}_{5}$ volumes of stocks of light oil products and gas at gas stations, motor gasoline, $t ; b_{6}$ - the number of lung ventilators; $b_{7}$ - the number of registered endocrine system diseases, eating disorders, metabolic disorders.

The quality description of the model shows a sufficient quality of fitting the model to the studied variables; all values of t-statistics are greater than critical. Such factors as light oil products and gas stocks, the number of migratory lung ventilators and carbon emissions positively correlate with the number of fatalities, the rest - harmful. Similar to the previous study, we will carry out an additional check for the presence or absence of a relationship between two sets: the values of the dependent variable: number of confirmed deaths from COVID-19 and the set of values that were included in the model (11), we use canonical analysis and univariate tests of significance, effect sizes, and powers for sigma-restricted parameterization. The results of canonical analysis (table 4) confirmed the presence of relationship between the explained variable and the independent ones because the indicator total redundancy is $79 \%$ at the p-value equal 0,000086 that means: the variation of the number of confirmed cases of coronavirus by $79 \%$ is explained by exactly 7 considered repressor's. Also, the value of the actual chi-square $(30,24)$ significantly exceeds the critical value $(13,85)$, which confirms the presence of a close relationship of factors $b_{i}, i=1 . .7$, which were included in the model (11) and the number of confirmed deaths from COVID -19. The analyses of sigmarestricted parameterization also provided confirmation of the significance of the input data: the $\mathrm{R}$ square value for the indicators (the number of registered endocrine system diseases, eating disorders, metabolic disorders, the number of lung ventilators, volumes of stocks of light oil products and gas at gas stations, motor gasoline) is over 0,608, indicating that these data describe the model satisfactorily. For indicators: registered unemployment on average for the period, volumes of waste accumulated during operation, in specially designated places and facilities $\mathrm{R}$ square is in the range of $0,43-0,49$, but with an average $\mathrm{p}$-value of 0,05 , which is also confirms the significance of these factors for the dependent variable number of confirmed deaths from COVID.

Table 8 . The most significant variables

\begin{tabular}{|c|c|c|c|c|c|c|}
\hline & Beta* $^{*}$ & $\begin{array}{l}\text { Std.Err. - } \\
\text { of Beta* }\end{array}$ & $\mathrm{B}^{*}$ & $\begin{array}{l}\text { Std.Err. - } \\
\text { of B* }\end{array}$ & $\mathrm{t}(17)^{*}$ & p-level* \\
\hline Free member of the regression & - & - & 1255,9 & 1018,5 & 1,2330 & 0,2343 \\
\hline $\begin{array}{l}\text { The endocrine system diseases, eating } \\
\text { disorders }\end{array}$ & 0,3815 & 0,1784 & 0,008 & 0,004 & 2,1384 & 0,0472 \\
\hline $\begin{array}{l}\text { Registered unemployment on average } \\
\text { over the period }\end{array}$ & $-0,2779$ & 0,1587 & $-6,514$ & 3,721 & $-1,7506$ & 0,0980 \\
\hline Number of lung ventilators & 0,3412 & 0,1852 & 1,176 & 0,638 & 1,8416 & 0,0830 \\
\hline $\begin{array}{l}\text { Emissions of carbon dioxide into the } \\
\text { atmosphere by regions, thousand tons }\end{array}$ & $-0,2373$ & 0,1646 & $-0,005$ & 0,004 & $-1,4413$ & 0,1676 \\
\hline $\begin{array}{l}\text { Volume of accumulated waste, } \\
\text { thousand tons }\end{array}$ & $-0,3182$ & 0,1715 & $-0,000$ & 0,000 & $-1,8555$ & 0,0809 \\
\hline
\end{tabular}




\begin{tabular}{|c|c|c|c|c|c|c|}
\hline $\begin{array}{l}\text { Stocks of light oil products and gas } \\
\text { (motor gasoline) - total, tons }\end{array}$ & 0,3764 & 0,2177 & 0,029 & 0,017 & 1,7283 & 0,1020 \\
\hline $\begin{array}{l}\text { Use of working time and part-time } \\
\text { work, hours }\end{array}$ & $-0,1969$ & 0,1566 & $-3,109$ & 2,473 & $-1,2572$ & 0,2256 \\
\hline
\end{tabular}

* Symbols: Beta Std.Err. - of Beta - standardized regression coefficient and its standardized error; B / Std.Err. - of B - non-standardized regression coefficient and its standardized error; $\mathrm{t}$ (17) - $\mathrm{t}$ - statistics with the number of freedom degrees 17; $\mathrm{p}$-level - the significance level of the coefficient; Multiple - R - multiple correlation coefficient; Multiple - R-square - determination coefficient; Adjusted R-square is a determination coefficient adjusted for the number of freedom degrees.

Source: own calculation

The adjusted correlation coefficient in Table 8 indicates an average relationship between predicates and the dependent variable with the number of indices $n=7$. So we will construct a multiple quadratic regression:

$$
\begin{gathered}
z=4,3 \cdot 10^{-1} b_{1}^{2}-22,7 b_{1}-1,5 b_{2}^{2}+10,5 b_{2}-7,2 \cdot 10^{-8} \cdot b_{3}^{2}-4,5 \cdot 10^{-3} b_{3}-8,4 \\
\cdot 10^{-12} b_{4}^{2}+3,2 \cdot 10^{-5} b_{4}+1,3 \cdot 10^{-5} b_{5}^{2}-8,6 \cdot 10^{-2} b_{5}+8,4 \cdot 10^{-3} b_{6}^{2} \\
-8,8 \cdot 10^{-1} b_{6}-2,2 \cdot 10^{-7} b_{7}^{2}+1,9 \cdot 10^{-2} b_{7}+1453,4 \\
F_{e m}=3,5, F_{t a b}(0,05 ; 7 ; 17)=2,6 .
\end{gathered}
$$

$D W=1,89$, the Darbin-Watson test indicates a little autocorrelation of the residuals. The heteroskedasticity hypothesis in the model is rejected using the Spearman test.

We compare the frequency histograms of theoretical and empirical values of the confirmed deaths from COVID-19 (Fig. 6, 7).

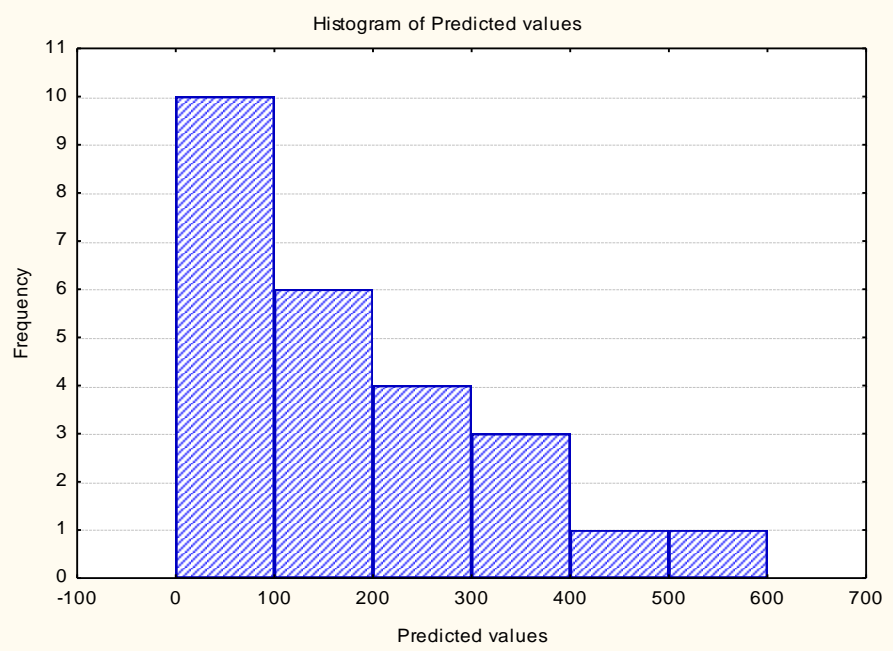

Figure 6. The relative frequency of theoretical values of deaths number from COVID-19

Source: own compilation

Thus, Figure 6 shows that the relative frequency is completely the same for regions with low (0-100 cases) and high mortality levels (400-600). There is a distortion between the data of $100-400$, probably caused by the fact that there is a strong differentiation of regions by this index, and the real data are not normally distributed. 


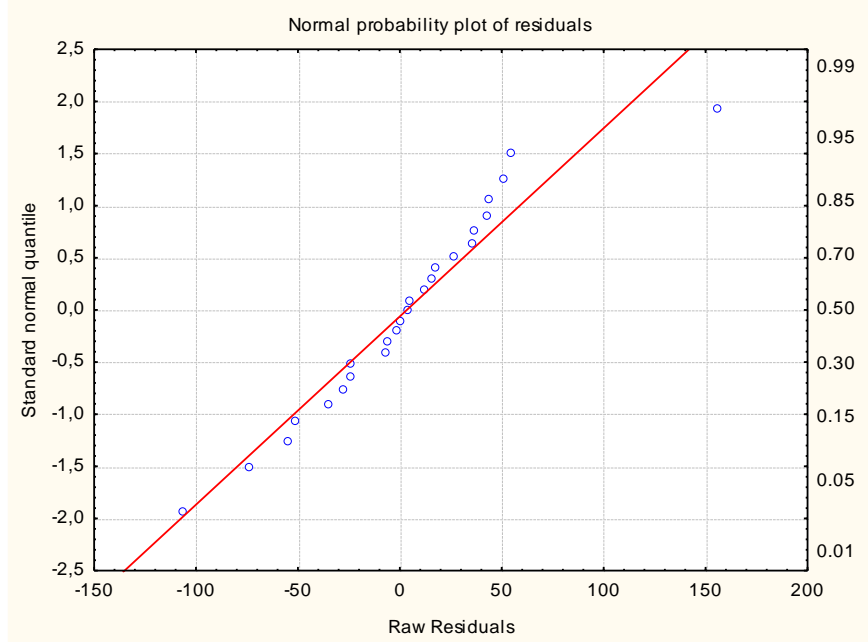

Figure 7. The relative frequency of empirical values of the deaths number from COVID-19 Source: own compilation

Table 9 shows data to compare theoretical and empirical data (Response - Value and Pred. - Value) regarding the number of confirmed deaths from COVID-19 and standardized residuals, according to which anomalous emissions from the model exist in such regions as Zakarpattia, Zaporizhia, Kyiv, Luhansk, Ternopil and Chernivtsi regions. 
Table 9. Results of the quadratic regression model for the regressor: the number of deaths from COVID-19 for the Ukrainian regions

\begin{tabular}{|c|c|c|c|c|}
\hline & $\begin{array}{c}\text { General.-Cook's } \\
\text { D* }\end{array}$ & Std. P. - Residual* & Response-Value* & Pred.-Value* \\
\hline Vinnytsia region & 14,6488 & $-1,40910$ & 119,0000 & 143,5070 \\
\hline Volyn region & 1,0228 & 1,12938 & 174,0000 & 131,6462 \\
\hline $\begin{array}{l}\text { Dnepropetrovsk } \\
\text { region }\end{array}$ & - & - & 125,0000 & 124,8751 \\
\hline Donetsk region & 0,0059 & 1,09029 & 56,0000 & 1,2501 \\
\hline Zhytomyr region & 0,0778 & 0,76840 & 113,0000 & 76,6410 \\
\hline Zakarpattia region & 178,7785 & $-3,75447$ & 310,0000 & 361,0941 \\
\hline Zaporizhya region & 51,6454 & $-2,91926$ & 70,0000 & 125,3062 \\
\hline $\begin{array}{l}\text { Ivano-Frankivsk } \\
\text { region }\end{array}$ & 280,3286 & 2,44252 & 331,0000 & 313,2507 \\
\hline Kyiv region & 53,4271 & $-2,29869$ & 199,0000 & 233,7146 \\
\hline Kirovograd region & 0,0975 & 0,76727 & 60,0000 & 24,2238 \\
\hline Luhansk region & 54,0827 & $-4,24808$ & 16,0000 & 122,9651 \\
\hline Lviv region & 405,1779 & 2,46430 & 573,0000 & 557,9254 \\
\hline Mykolayivska region & 0,0020 & 0,10890 & 82,0000 & 76,9289 \\
\hline Odessa region & 92,5583 & $-2,32771$ & 217,0000 & 244,5553 \\
\hline Poltava region & 27,5533 & $-0,88502$ & 44,0000 & 51,4070 \\
\hline Rivne region & 1,5573 & 1,37297 & 171,0000 & 119,8544 \\
\hline Sumy region & 0,0149 & $-0,15871$ & 77,0000 & 83,3311 \\
\hline Ternopil region & 80,9138 & $-3,79654$ & 171,0000 & 245,3152 \\
\hline Kharkiv region & 103,7452 & 2,34406 & 364,0000 & 337,5360 \\
\hline Kherson region & 0,0351 & $-0,51621$ & 26,0000 & 50,4264 \\
\hline Khmelnytsky region & 1,2473 & 1,18541 & 131,0000 & 87,5664 \\
\hline Cherkasy region & 0,0002 & $-0,02935$ & 59,0000 & 60,3308 \\
\hline Chernivtsi region & 12,8129 & 4,09810 & 365,0000 & 209,6272 \\
\hline Chernihiv region & 0,0086 & 0,25258 & 77,0000 & 65,0638 \\
\hline Kyiv & 55,6128 & 0,73019 & 413,0000 & 409,4180 \\
\hline
\end{tabular}

*Symbol: General. - Cook's D - Cook's distance; Response - Value - empirical values; Pred. Value - theoretical values; Residual - residuals; St. - Error - standard error.

Source: own calculation

A quadratic function is used to build the regression model. There are critical values at which the regression will take extreme values. Then, we find the critical values of the function for each variable (using a differential calculus) and critical minimum and maximum points.

The optimal values of each parameter have been found, at which either the greatest or the smallest influence on the dependent variable is achieved, using the differentiation function of many variables (7).

\section{Conclusion}

Thus, the determination of critical values for the defined models allow forming the optimal variables for the number of confirmed cases of death and mortality from COVID-19.

We obtained a corresponding result for the index characterizing the COVID-19 incidence, using the above technique.

1. The number of interstate migrants: $a_{1, \min }^{*}=1782,4$ peple; input data range from -979 to 854 .

2. Volumes of carbon dioxide emissions into the atmosphere $a_{2, \min }{ }^{*}=16998,8$ thousand $\mathrm{t}$; input data range from 142 to 23528. 
3. The amount of waste accumulated during operation, $a_{3, \min }{ }^{*}=174374,3$ thousand $\mathrm{t}$; input data range from 578 to 10689892.

4. The number of medical care contracts under the medical guarantees program $a_{5, \min }{ }^{*}=214,9$; input data range from 121 to 503 .

5. Number of beds in infectious diseases departments $a_{6, \max }{ }^{*}=949260,1$ pcs.; input data range from 198 to 1964.

6. Number of specialized doctors (infectologists, therapists, pediatricians) $a_{7, \min }{ }^{*}=644,7$ people; input data range from 89 to 397 .

We will obtain the following result for the index characterizing mortality from COVID19:

1. The level of registered unemployment, $b_{1, \min }^{*}=25,9$ thousand $\mathrm{t}$; input data range from 5,5 to 27,7 .

2. Volumes of working time per full-time employee, $b_{2, \max }^{*}=347,6$ hours; input data range from 403 to 435 .

3 . Volumes of carbon dioxide emissions into the atmosphere $b_{3, \max }^{*}=31341,2$ thousand $t$; input data range from 142,3 to 23528,1 .

4. Volumes of waste accumulated during operation $b_{4, \max }^{*}=1897111$ thousand $\mathrm{t}$; input data range from 578,9 to 10689892,0 .

5. Stocks of light oil products and gas at gas stations $b_{5, \min }^{*}=3249,3 \mathrm{t}$; input data range from 1545,15 to 9605,0 .

6. Number of artificial lung ventilators $b_{6, \min }^{*}=52$; input data range from 32 to 193.

7. The number of registered endocrine system diseases, eating disorders, metabolic disorders $b_{7, \text { max }}^{*}=41711,5$; input data range from 4353 to 32634 .

Evaluation of relevant socio-environmental and economic indices regarding their impact on the mortality rate from COVID-19 confirms the hypotheses regarding the effect of registered unemployment, working hours per employee, carbon dioxide emissions, the amount of registered endocrine system diseases, eating disorders, metabolic disorders for mortality from COVID-19, formed at the beginning of the study.

The study of the impact made by relevant socio-ecological and economic indices on the COVID-19 incidence confirms the hypotheses on the effect of the following indices: the number of interstate migrants, carbon dioxide emissions into the atmosphere, the amount of waste accumulated during operation.

The obtained results will allow making appropriate adjustments in advance to the state and regional programs for mobilization of the economy and the medical system, to carry out reactive and preventive control of the pandemic consequences.

\section{Acknowledgement}

Current study was the part of research work of "Economic and mathematical modelling and forecasting impact of COVID-19 on the development of Ukraine in national and regional contexts: public health and socio-ecological-economic factors determinants" (number of state registration 0120U104784).

This work was supported by the Slovak Research and Development Agency under the contract No. APVV-19-0579. 


\section{References}

Arndt, C., Lewis, J. (2001). The HIV|AIDS pandemic in South Africa: sectoral impacts and unemployment. Journal of International Development, 13(4), 427- 449.

Bagmet, K.V., Haponova, O. (2018). Assessing the Impact on Social Sector: A Macroeconomic Approach. SocioEconomic Challenges, 3(2), 103-108. doi:10.21272/sec.3(2).103108.2018.

Bai,Y., Yao, L., \& Wei, T. (2020). Presumed Asymptomatic Carrier Transmission of COVID19. Journal of the American Medical Association.323(14), 1406-1407. doi:10.1001/jama.2020.2565.

Bell, M., McDermott A., Zeger, S., Samet, J., Dominici, F., (2004). Ozone and short-term mortality in 95 US urban communities. Journal of the American Medical Association. 292(19), 2372-2380.

Bhargava, A., Jamison, D., Lau, L., Murray, C. (2001). Modeling the effects of health on economic growth. Journal of Health Economics. 20(3), 423-40. doi: 10.1016/s01676296(01)00073-x.

Bilan, Y., Lyeonov, S., Stoyanets, N., \& Vysochyna, A. (2018). The impact of environmental determinants of sustainable agriculture on country food security. International Journal of Environmental Technology and Management, 21(5-6), 289-305. doi:10.1504/IJETM.2018.100580.

Bilan, Y., Raišienè, A. G., Vasilyeva, T., Lyulyov, O., \& Pimonenko, T. (2019). Public governance efficiency and macroeconomic stability: Examining convergence of social and political determinants. Public Policy and Administration, 18(2), 241-255. doi:10.13165/VPA-19-18-2-05

Bobáková, V.(2017). The Formation of Regional Self-government in the Slovak Republic and its Sources of Funding. Administratie si Management Public, 28, 97-115. Retrieved from: https://www.ceeol.com/search/journal-detail?id=534.

Bryl, Ł. (2020). Long-term Development of National Human Capital. Evidence from China and Poland. Journal of Intercultural Management, Vol. 12 | No. 2 |June 2020 | pp. 30-66 DOI 10.2478/joim-2020-0044.

Cebula, J., Chygryn, O., Chayen, S. V., \& Pimonenko, T. (2018). Biogas as an alternative energy source in ukraine and israel: Current issues and benefits. International Journal of Environmental Technology and Management, 21(5-6), 421-438. doi:10.1504/IJETM.2018.100592.

Çera, G., Belas, J., Rozsa, Z., \& Cepel, M. (2019). Linking firm characteristics to perceived important social factors for entrepreneurial activity. Economics and Sociology, 12(4), 101-115. doi:10.14254/2071-789X.2019/12-4/6.

Chen, Z., Zhang, Q., Lu, Y., Guo, Z., Zhang, X., Zhang, W., Guo, C., Liao, C., Li, Q., Han, X., \& Lu, J. (2020). Distribution of the COVID-19 epidemic and correlation with population emigration from Wuhan. Chinese Medical Journal, 133(9), 1044-1050 doi: 10.1097/CM9.0000000000000782.

Chygryn, O., Petrushenko, Y., Vysochyna, A., \& Vorontsova, A. (2018). Assesmentof fiscal decentralization influence on social and economic development, Montenegrian Jornal of economics, 14(4), 69-84.

Cristea, L.A, \& Grabara, J. (2019). Fiscal impact of the migration phenomenon. Journal of International Studies, 12(4), 144-159. doi:10.14254/2071-8330.2019/12- 4/10.

Cuddington, T., Hancock, J. (1994) Macroeconomic Impact of AIDS in Malawi: a Dualistic, Labour Surplus Economy. Journal of African Economies, 4(1), 1-28. 
Dave, H. (2019). The X-ray report of "Economic growth". Financial Markets, Institutions and Risks, 3(4), 89-93. doi: 10.21272/fmir.3(4).89-93.2019.

Didenko, I., Paucz-Olszewska, J., Lyeonov, S., Ostrowska-Dankiewicz, A., \& Ciekanowski, Z. (2020a). Social safety and behavioral aspects of populations financial inclusion: A multicountry analysis. Journal of International Studies, 13(2), 347-359. doi:10.14254/2071-8330.2020/13-2/23

Didenko, I., Volik, K., Vasylieva, T., Lyeonov, S., \& Antoniuk, N. (2020b). Migration, environment, and country safety: Analysis of touchpoints. Paper presented at the E3S Web of Conferences, 202. doi:10.1051/e3sconf/202020203028

Djalilov, K., Lyeonov, S., \& Buriak, A. (2015). Comparative studies of risk, concentration and efficiency in transition economies. Risk Governance and Control: Financial Markets and Institutions, 5(4CONT1), 178-187. doi:10.22495/rgcv5i4c1art7

Dutta, P., Dutta,U., Hasan, S., Sarkar, N., \& Sana, T. (2020). Educate, empower and protect people through timely authentic information: explore how Bangladeshi newspapers response to COVID-19 pandemic. SocioEconomic Challenges, 4(3), 94-104. doi:10.21272/sec.1(3).94-104.2020

Farseev, A., Chu-Farseeva, Y., Yang, Q., Loo, D. (2020). Understanding Economic and Health Factors Impacting the Spread of COVID-19 Disease. MedRxiv, doi:10.1101/2020.04.10.20058222.

Grabara, J., Cehlar, M., \& Dabylova, M. (2019). Human factor as an important element of success in the implementation of new management solutions. Polish Journal of Management Studies, 20(2), 225-235. doi: 10.17512/pjms.2019.20.2.19

Grshybowskyj, J. L., Smiianov, V. A., Myronyuk, I. M., \& Lyubinets, O. V. (2019). Ten indicators which characterize medical-demographic processes in adjacent regions of Ukraine and Poland. Wiadomosci Lekarskie, 72(51), 868-876. Retrieved from https://www.scopus.com/record/display.uri?eid=2-s2.0-85068474808\&origin=resultslist

Harafonova, O., Zhosan, G., \& Akimova, L. (2017). The substantiation of the strategy of social responsibility of the enterprise with the aim of providing efficiency of its activities . Marketing and Management of Innovations, doi: 10.21272/mmi.2017.3-25.

Hedvicakova, M., Sokolova, M., \& Mohelska, H. (2018). The impact of economic growth on wages and the supply of employee benefits in the Czech republic. Transformations in Business \& Economics, 17(3), 45.

Hens, L., Melnyk L., Matsenko, O., Chygryn, O., \& Gonzales, C. C. (2019). Transport economics and sustainable development in Ukraine. Marketing and Management of Innovations, 3, 272-284. http://doi.org/10.21272/mmi.2019.3-21

Yelnikova, J., \& Kwilinski, A. (2020). Impact-Investing in The Healthcare in Terms of the New Socially Responsible State Investment Policy. Business Ethics and Leadership, 4(3), 5764. doi:10.21272/bel.4(3).57-64.2020.

Jafarzadeh, E., \& Shuquan, He. (2019). The Impact of Income Inequality on the Economic Growth of Iran: An Empirical Analysis. Business Ethics and Leadership, 3(2), 53-62. doi.org/10.21272/bel.3(2).53-62.2019.

Ji, Y., Ma, Z., Peppelenbosch, M., Pan, Q. (2020) Potential association between COVID-19 mortality and health-care resource availability. Lancet Glob Health. doi:10.1016/S2214109X(20)30068-1.

Kashyap, G.C., Puri, P., \& Singh, S. K. (2020). Respiratory Health Upshots due to Contaminated Living Environment: A Cross-Sectional Study of the Industrial Belt of Kanpur City, India. SocioEconomic Challenges, 4(1), 17-27. doi: 10.3139/124.110800. 
Khomenko, L., Saher, L., \& Polcyn, J. (2020). Analysis Of The Marketing Activities In The Blood Service: Bibliometric Analysis. Health Economics and Management Review, 1, 20-36. https://doi.org/10.21272/hem.2020.1-02.

Kot, S. M. (2020). Estimating the parameter of inequality aversion on the basis of a parametric distribution of incomes. Equilibrium. Quarterly Journal of Economics and Economic Policy, 15(3), 391-417. https://doi.org/10.24136/eq.2020.018.

Kusuma, A., Praja, A., Takarinawati, S., Roespinoedji, D., \& Zainudin, Z. (2020). The mediating role of mindset priming on the long-term investment intention. Polish Journal of Management Studies, 21(1). 316-327. DOI: 10.17512/pjms.2020.21.1.23.

Lapinskienè, G., Peleckis, K., \& Slavinskaite, N. (2017) Energy consumption, economic growth and greenhouse gas emissions in the European Union countries, Journal of Business Economics and Management, 18:6, 10821097, doi:10.3846/16111699.2017.1393457.

Lee, J., \& Mckibbin, W., Globalization and disease: The case of SARS (2004). Asian Economic Papers, 3(1), 113-131, doi:10.1162/1535351041747932.

Levchenko V., Boyko A., Bozhenko V. Savchenko T., Humenna Y., \& Pilin R. (2019). State regulation of the economic security by applying the neoteric approach to its assessment. Marketing and Management of Innovations, 4, 364-372. DOI: 10.21272/mmi.2019.4-28.

Lewandowska, A., \& Stopa, M. (2020). The impact of innovative professional qualifications on the sense of employment security: Evidence from Poland. Economics and Sociology, 13(3), 72-83. doi:10.14254/2071-789X.2020/13-3/5.

Liu, J., Curry, J., Rossow, W., Key, J., \& Wang, X. (2005). Comparison of surface radiative flux data sets over the Arctic Ocean. Journal of Geophysical Research, 110, C02015, doi:10.1029/2004JC002381.

Luchko, M., Arzamasova, O., \& Vovk, I. (2019). Personnel potential of national economy and gross domestic product: The case of Ukraine. Montenegrin Journal of Economics, 15(2), 59-70.

Lyulyov, O., \& Shvindina, H. (2017). Stabilization pentagon model: Application in the management at macro- and micro-levels. Problems and Perspectives in Management, 15(3), 42-52. doi:10.21511/ppm.15(3).2017.04

Lyulyov, O., Chortok, Y., Pimonenko, T., \& Borovik, O. (2015). Ecological and economic evaluation of transport system functioning according to the territory sustainable development. International Journal of Ecology and Development, 30(3), 1-10. Retrieved from https://www.scopus.com/record/display.uri?eid=2-s2.084940377261\&origin=resultslist.

Melnyk, L., Sineviciene, L., Lyulyov, O., Pimonenko, T., \& Dehtyarova, I. (2018). Fiscal decentralization and macroeconomic stability: The experience of ukraine's economy. Problems and Perspectives in Management, 16(1), 105-114. doi:10.21511/ppm.16(1).2018.10.

Meltzer, M., Cox, N., \& Fukuda, K. (1999). The economic impact of pandemic influenza in the United States: priorities for intervention. Emerging Infectious Diseases, 5, 659-71. doi: 10.3201/eid0505.990507.

Mentel, G., Vasilyeva, T., Samusevych, Y., \& Pryymenko, S. (2018). Regional differentiation of electricity prices: Social-equitable approach. International Journal of Environmental Technology and Management, 21(5-6), 354-372. doi:10.1504/IJETM.2018.100583.

Osabohien, R., Onanuga, O., Aderounmu, B., Matthew, O., \& Osabuohien, E. (2020). Social protection and employment in Africa's agricultural sector. Business: Theory and Practice, 21(2), 494-502. https://doi.org/10.3846/btp.2020.11945. 
Papo, D., Righetti, M., Fadiga, L., Biscarini, F., \& Zanin, M. (2020). A minimal model of hospital patients' dynamics in COVID-19. Chaos Solitons and Fractals,140,1-6. DOI: 10.1016 / j.xaoc. 2020.110157.

Rajan, D. (2018). Personal and Social Perception of Occupational Hazards by Health Care Workers: A Study among Radiographers. Business Ethics and Leadership, 2(4), 46-63. DOI: $10.21272 / \mathrm{bel} .2(4) .46-63.2018$.

Rudenko, L. A., Smiianov, V. A., \& Smiianova, O. I. (2020). Basic principles of behavioral economics and prospects for their application in the public health system. Wiadomosci Lekarskie. 73(9), 2026-2030. doi:10.36740/wlek202009225.

Rui, L., Sineviciene, L., Melnyk, L., Kubatko, O., Karintseva, O., \& Lyulyov, O. (2019). Economic and environmental convergence of transformation economy: The case of china. Problems and Perspectives in Management, 17(3), 233-241. doi:10.21511/ppm.17(3).2019.19.

Sasongko, G., \& Huruta, A. D. (2019). The causality between inflation and unemployment: the Indonesian evidence. Business: Theory and Practice, 20, 1-10. https://doi.org/10.3846/btp.2019.01.

Senol, Z., Zeren, F., \& Canakci, M. (2020). The Relationship between insurance and economic growth. Montenegrin Journal of Economics, 164, 145-155.

Shammi, M., Bodrud-Doza, M., Islam, ARMT, \& Rahman, MM. (2020). Strategic assessment of COVID-19 pandemic in Bangladesh: comparative lockdown scenario analysis, public perception, and management for sustainability. Environ Dev Sustain., Mol 7, 1-44. doi:10.20944/preprints202004.0550.v1

Smiianov, V. A. (2014). Internal audit-the foundation of healthcare quality management in health care. Wiadomości Lekarskie (Warsaw, Poland : 1960), 67(2), 381-383. Retrieved from https://www.scopus.com/record/display.uri?eid=2-s2.084937511729\&origin=resultslist

Smiianov, V. A., Smiianova, O. I., Gruzieva, T. S., Vygivska, L., \& Rudenko, L. A. (2017). Study of motivational factors in doctors in respect of healthcare quality improvement. Wiadomosci Lekarskie (Warsaw, Poland : 1960), 70(1), 27-31. Retrieved from https://www.scopus.com/record/display.uri?eid=2-s2.0-85023623493\&origin=resultslist

Sokol, V. K., Kolesnichenko, V. A., Sokol, K. M., \& Smiianov, V. A. (2020). Method of forensic assessment of risk factors of treatment failure outcomes as an element of quality management of medical care. Wiadomosci Lekarskie (Warsaw, Poland: 1960), 73(5), 1041-1047. Retrieved from https://www.scopus.com/record/display.uri?eid=2-s2.085084721368\&origin=resultslist

Sułkowski, Ł. (2020). Covid-19 Pandemic; Recession, Virtual Revolution Leading to Deglobalization? Journal of Intercultural Management. 12(1), 1-11. DOI 10.2478/joim2020-0029

Sumiyana, S. (2020). Different characteristics of the aggregate of accounting earnings between developed and developing countries: Evidence for predicting future GDP. Journal of International Studies, 13(1), 58-80. doi:10.14254/2071- 8330.2020/13-1/4

Svabova, L., Kramarova, K., Chutka, J., \& Strakova, L. (2020). Detecting earnings manipulation and fraudulent financial reporting in Slovakia. Oeconomia Copernicana, 11(3), 485-508. https://doi.org/10.24136/oc.2020.020.

Tunčikienè, Ž. \& Drejeris, R. (2017) Assessment of business conditions benevolence: case of occupational safety and health services. Journal of Business Economics and Management, 18:3, 505-520, doi:10.3846/16111699.2017.1333524.

Vasilyeva, T., Kuzmenko, O., Bozhenko, V., \& Kolotilina, O. (2019). Assessment of the dynamics of bifurcation transformations in the economy. Paper presented at the CEUR 
Workshop Proceedings, 2422, 134-146. Retrieved from https://www.scopus.com/record/display.uri?eid=2-s2.0-85071124329\&origin=resultslist Vydrová, J., \& Bejtkovský, J. (2018). The importance of the individual pillars of social maturity of workers in healthcare organizations in the hierarchy of pillars of competence in management. Administratie si Management Public, 31, 21-35. 